\title{
A Conceptual Framework For Electrical Engineering Education Curriculum Using CIPP Evaluation Model
}

\author{
Nurulita Imansari (Author) \\ Doctoral Student of Vocational Education, Postgraduate \\ State University of Malang \\ Malang, Indonesia \\ nurulita.imansari@gmail.com
}

\begin{abstract}
This evaluation is a conceptual framework that has been studied in hopes of helping research related to the evaluation of the curriculum. The model of evaluation used is the model CIPP. CIPP model is composed of four dimensions of context, input, process, and product. In the context dimension within the framework of this conceptual includes a vision mission of study program, the purpose of the study program. On the input dimension consist of learning outcomes, curriculum structure relating to the subjects and their study materials, knowledge, skill and suitability of the field lecturer of the course, planning and preparations made lecturers (course outline). On the dimension of the process consists of lectures, practical implementation of the industry, PPL and $\mathrm{KKN}$, facilities, infrastructure, learning strategies, resources and instructional media and learning evaluation. On the dimension of products consists of the absorption of graduates by the world of work and suitability of competencies acquired during the lectures with the of the workforce.
\end{abstract}

Keywords-evaluation, curriculum, electrical engineering education, CIPP

\section{INTRODUCTION}

The impact of major global changes is the change of higher education system in the world able to meet challenge global. The challenge considered politics, education, quality and the effectiveness [1]. It is also an impact on the world of education in Indonesia. One effort to improve education in Indonesia is quality with Nawacita that proclaimed by the President of the Republic of Indonesia. Nawacita President of the Republic of Indonesia has put vocational education as a top priority the development of education in Indonesia. Presidential Instruction No. 9 Year 2016 on vocational revitalization in order to Improve the Quality and Competitiveness of Human Resources Indonesia which is the direction of development of vocational education in the future. Where is the role of universities that have two 1) accelerate the provision of vocational teachers through education, equality and recognition; and 2) develop a program of study in the University to produce the required vocational teachers. On this basis, Electrical Engineering Education of the University of PGRI Madiun has a role to generate productive vocational teachers in electrical engineering.
Preparation productive teacher is of course also have to follow the development of education at this time. Changes in educational orientation of competencies to the capabilities have become common in the world's awareness of vocational education over the past decade [2]. As stated also by Stephenson \& Weil [3] , one of the forms that challenge the old concept of learning is competence-oriented to the conceptual learning model. The extension of the competency model to capability model is a fundamental change of orientation and focus of vocational education in the second decade of the XXI Century, namely what we are familiar with the shifting of the paradigm of "teaching" to the paradigm of "learning", or orientation "job" expanded orientation to "life", which provide growth opportunities independence. It is also in accordance survey by the World Innovation Summit for Education: School in 2030 data showed that $75 \%$ of respondents said that personal skills will be an important base of education in the future.

Noonan [4] there is a discrepancy between the things students expect when they graduate and what schools prepare for students to do. Hence the relevance of the curriculum becomes very important. The hope is that what is gained students on campus will be in accordance with what the community needs. Curriculum evaluation could certainly be one of the steps in order to align their curricula with the demands of society. Therefore the evaluation results can be used as the basis for changes.

This paradigm shift must be supported by a review of the curriculum used. Because the curriculum is the basis of change in the world of education. The curriculum is a concept of study. The student must follow the curriculum in their institution. The definition of curriculum widely used to contract between the association, education professionals about the educational experience that learners have to experience during certain phases of life review. In the curriculum considered why, when, what, where, how and who can teach [5]. The revision of curriculum is a dynamic process. The revision process using need analysis issues global, goals and the result of evaluation from implementation curriculum [6].

In the fact to face the demands of the development of education is the need for evaluation of curriculum in Electrical Engineering Education. Curriculum evaluation is needed to 
determine Electrical Engineering Education curriculum implementation. The evaluation of curriculum quality shows the strength and weakness of the curriculum that was implemented in the learning system. The evaluation also considers the aims, learning strategy and time. The main point in this research is the evaluation process must be continued and dynamic. The dynamic process in this research means that the process following the change of science, technology, economic, social, cultural and political changing in the global.[7]

Furthermore, the results of this evaluation are to make a decision whether the curriculum currently applied permanent or needs to be upgraded through redesign curriculum. Curriculum evaluation is an activity that must be done as the end point of a curriculum development. Curriculum evaluation is also the starting point of the next curriculum development process. In a simple process that occurs can be described as a cycle that will never end. The process can be described as follows:

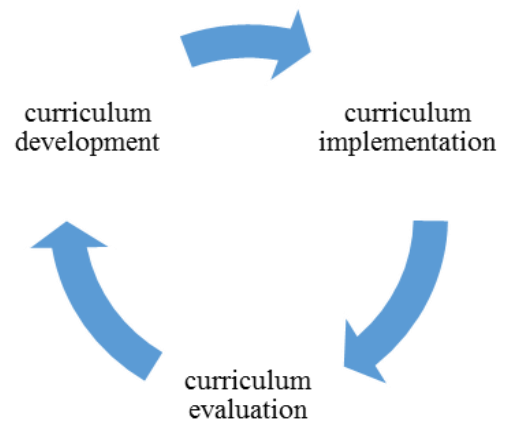

Fig 1. Cycle Curriculum

This cycle is a process that is interrelated and each stage must be passed in order to reach the next stage. If there is a stage that is passed then the next stage is a stage that has no basis. The three projects in the cycle must be carried out continuously and uninterrupted.

In the process of curriculum development is needed for a strong foundation so that the curriculum can later be produced in accordance with the needs of the community. Curriculum evaluation can be used as a basis for curriculum development. Such development must be based on several factors [8] namely 1) the development or discovery of new knowledge, 2) changes in the needs of society, 3) the development of government policies, 4) new ideas in the field of education, and 5) the weaknesses found the existing curriculum.

According to Nasution [9] evaluation model used is the model CIPP. CIPP Model is an abbreviation of context, input, process, and product. CIPP is an evaluation model that developed by Stufflebeam which aims to assist in the improvement of the curriculum, but also to decide whether the program was abandoned.

CIPP is one of evaluation model which have four level evaluation [10]. There are: Context used to evaluate principle of the object. Input used to evaluate the resource of the object. The process used to evaluate activities, the usage of objects. Resources. Product used to evaluate the relevance of object's resources with the given standard. According to the result of evaluation using CIPP model then can take a decision about the object to be continued, canceled, modified or expanded.

\section{RESEARCH METHOD}

This study aims to determine the dimensions of context, input, process, and product of the curriculum of Electrical Engineering Education, the Faculty of the Education University of PGRI Madiun.

This study uses a model of CIPP evaluation of Stufflebeam to identify the dimensions of context, input, process, and product. Reference [11] provides an explanation of each dimension of the CIPP evaluation:

1. Context: Evaluation This stage helps planning decisions, determine the need to be achieved by formulating programs and program objectives.

2. Input: The evaluation of this kind of help and arrange despair, determine the resources available, the alternative is taken, plans and strategies to achieve the requirements, work procedures how to achieve program objectives.

3. Process: The process evaluation is used to help provide and provide feedback information in order to implement the decision, the extent to which the plans or actions are going to be done to determine the implementation of the program is in accordance with the procedures and scheduling set.

4. Product: evaluation of products used to help subsequent decision, how results have been achieved and what will be done after the program is executed as well as measure the success of its goals have been set.

These four dimensions can be drawn as follows:

Context
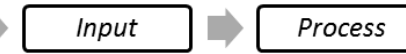

Product

Fig 2. Four Dimensions of CIPP Evaluation Model

\section{RESULTS AND ANALYSIS}

According to Hussain [12] good curriculum is 1) following the standard of good curriculum, 2) developed by social is sues, 3) using personal development, 4) continuing the experience education, 5) reach for the goal of education, 6) balance with the goal, 7) using effective learning and resources. Therefore, the evaluation has an important role to get a good curriculum. Seventh these characteristics can be obtained through the evaluation.

CIPP model is one of strategy to evaluated curriculum, so we can get a good curriculum. The revision curriculum will be proposed [13]:

1. Modified the learning outcomes by consulting alumni, labor market, as sociation

2. Mapping the new learning outcomes and also teaching strategies and as sessment

3. Defining the learning path through by means of curriculum

4. Discussing the discrepancy in learning path by study program team involved. 
5. Make the components adjustments in the standard structure, there are learning materials, learning strategies and assessments.

Evaluation of the context that gave birth to a curriculum document. This aspect of the demands of society for education and often referred to as a needs assessment. Need assessment carried out to determine what people need to be served by the Program. The conceptual dimension within the framework of this context includes vision and mission of the study program, the purpose of the study program.

Evaluation of input as sociated with the input, support, plans and strategies to implement the curriculum. On the input dimension consists of learning outcomes, curriculum structure relating to the subjects and their study materials, knowledge, skill and suitability of the field lecturer of the course, planning and preparations made lecturers (course outline).

Evaluation of process is the implementation of the curriculum in the study program. In this dimension, the curriculum implementation forms the main object of evaluation. On the dimension of the process consists of lectures, practical implementation of the industry, PPL and $\mathrm{KKN}$, facilities, infrastructure, learning strategies, resources and instructional media and learning evaluation.

Evaluation of results oriented products to determine a decision. The decision in question is whether to continue, modify, terminate the curriculum used today. On the dimension of products consists of the absorption of graduates by the world of work and suitability of competencies acquired during the lectures with the needs of the workforce.

Based on Fig 2, there are four dimensions evaluated that context, input, process, and product. The elements of each of these dimensions can be described as follows:

\section{Context}

- Vision and mission of the study program

-Purpose of the study program

$\cdot \mathrm{KKNI}$

\section{Input}

- Learning outcomes

- Lecturer background

- Knowledge and skill

- Course outline

\section{Process}

-Learning in the class

-PPL, KKN, Apprenticeship

- Facilities

-Infrastructure

- Learning strategy

- Learning resources and media

-Learning evaluation

\section{Product}

- Absorption of the graduates by the world of work

- Suintability of competencies acquired during the

lectures with the needs of the workforce

\section{CONCLUSION}

One model of evaluation that can be used to evaluate the curriculum is the CIPP model. CIPP model is composed of four dimensions of context, input, process, and product. In the context of the evaluation, the evaluators assess the needs, is sues and opportunities dab of assets as a basis to define and assess the objectives and priorities. In the input evaluation, the evaluators to identify and assess alternative approaches and plans to meet assessed needs and achieve the goals set. In the evaluation process, the evaluators to monitor, document and provide vituperation behind to strengthen the implementation of the curriculum. Whereas in product evaluation, the evaluators to identify and assess the positive results and negative results.

The advice given is in the evaluation curriculum using four dimensions of CIPP model must be done thoroughly. Curriculum evaluation should be done with the principle of goal-based evaluation that is based on objective evaluation

\section{ACKNOWLEDGMENT}

Thanks to University of PGRI Madiun

\section{REFERENCES}

[1] El- khawas, E. (2006). Accountability and quality assurance: new issues for academic inquiry.Springer International handbook of higher education, 18, 1, 23-37.

[2] Staron, M., Jasinski, M and Weatherley, R. (2006) Life-based Learning: A strength-based approach for capability development in vocational and technical education. Australian Government Department for Education Science and Training and T AFENSW Available on-line at:http://learningtobeprofessional.pbworks.com/w/page/32893040/Lifebased-learning, Accessed May 18, 2017

[3] Stephenson, J. \& Weil, S. (1992) Quality in Learning: A Capability Approach in Higher Education, Kogan Page, London

[4] Noonan, Linda. 2014. Education For The 21st Century Executice Summary A Synthesis of Ideas from the Harvard University Advanced Leadership Initiative Think Tank. April 24 to 26, 2014 Cambridge, MA

[5] T sui, C. (2009) Quality assurance in higher education: a Hong Kong perspective. PhD thesis, University College London

[6] Kirkgöz, Y. (2009). The challenge of developing and maintaining innovationat higher education curriculum, Procedia Journal of Social and Behavioral Sciences, 1, 73-78.

[7] Keramati, M. R., \& Ahmadi, A. (2011). The quality curriculum evaluation in postgraduate studies of Educational Management and Planning in the public Universities of Tehran City. Procedia-Social and Behavioral Sciences, 15, 3723-3730.

[8] Rohizani Yaakub \& Mohd. Zohir Ahmad (2007) Pedagogy: Strategies and Techniques of Teaching With Memorable. Kuala Lumpur: PTS Professional Publishing Sdn Bhd

[9] Nasution, S. 2010. Kurikulum dan Pengajaran. Jakarta: Bumi Aksara

[10] Pitiyanuwat, S. (2006) Evaluation Methodology: The Art of Evaluation. $3^{\text {rd }}$ ed., (Bangkok, Chulalongkrong University Publication)

[11] Mbulu, Joseph. 1995. Evaluasi Program Konsep Dasar, Pendekatan, Model dan Prosedur Pelaksanaan. IKIP Malang

[12] Hussain, Afzaal. 2011. Evaluation of Curriculum Development Process. International Journal of Humanities and Social Science. Vol. 1 No. 14, October 2011

[13] Building the curriculum in higher education: a conceptual framework: Nicole Totté*, Steven Huyghe* \& AlexandraVerhagen, Academic Development Unit, KU Leuven, Belgium*equal contribution. 